\title{
CAD 標準化フォーマット
}

\author{
星合 文広*
}

\section{Standard Format for CAD System}

Fumihiro HOSHIAI *

*日本電気株式会社電子部品事業本部回路基板事業部（２29 神奈川県相模原市南橋本3-1-35）

* Printed Wiring Board Division, NEC Corporation (3-1-35 Minami-Hashimoto, Sagamihara-shi, Kanagawa 229)

\section{1.はじめに}

プリント配線板（以下 PWB と称す）の設計・製 造には CAD/CAM システムが不可欠であり, 現在 国内外の各ベンダから数十種の CAD システムが販 売され，それぞれの特徴・仕様に応じて各ユーザに て運用されている。

しかし，現在異機種 CAD 間で設計データを送受 しょうとした場合, CAD 単位でデータフォーマット が異なるため，困難である。また，上流工程である 回路設計用 $\mathrm{CAD}$ と $\mathrm{PWB}$ パターン設計用 $\mathrm{CAD}$ の 間, および PWB 製造・検査工程の CAM/CAT との 間も，一部を除きデータフォーマットが統一されて おらず，個別に変換ソフトを作成して対応している のが現状である。

これらのデータフォーマットの不統一は, PWB の設計・製造工程における自動化・合理化を阻害す る大きな要因となっており, フォーマットの標準化 が，特に CAD ユーザから強く望まれている。

このような背景のもとで, 現在 PWB の CAD デ ータフォーマット標準化の推進として，2 つの大き な流れがある。

1 つは日本プリント回路工業会 (JPCA) が中心と なり，国内 $\mathrm{CAD}$ ベンダおよびユーザが集まり作成 した「JPCA データフォーマット」であり，すでに VER. 1 が完成し, 現在各 CAD ベンダが本フォーマ ット対応のソフト開発に着手している状況である。

もうひとつは，アメリカEIAが推進している EDAの国際標準フォーマット EDIF (Electronic
Design Intercharge Format)である。この PWBレ イアウト版であるV400が現在検討されており，今 年度中にリリースされる予定である。日本において は日本電子機械工業会が中心となり，推進活動を行 っている。

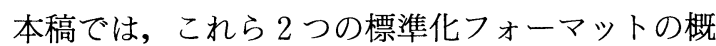
要について解説する。

\section{2. 多様化する情報インタフェース}

図 1 は PWB のユーザである装置メーカと, PWB 設計・製造メーカの間の CAD 情報インタフェース のニーズを示したものである11。

PWB ユーザ PWBメーカ

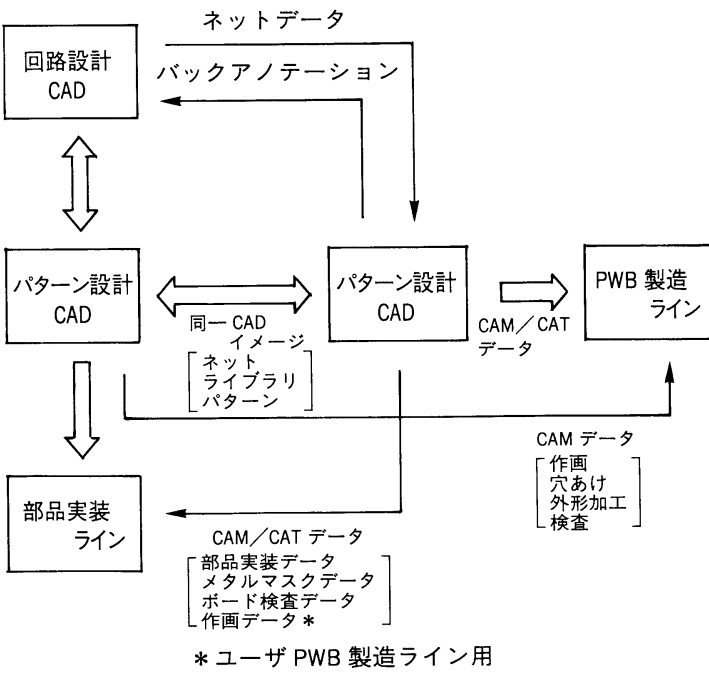

図 1。多様化するCAD 情報インタフェース 
回路設計用 $\mathrm{CAD}$ とパターン設計用 $\mathrm{CAD}$ の間で はネットリストの送受が行われるが，特に配置・配 線結果に基づくピン割り付けや部品名変更などのい わゆるバックアノテーション情報を戻す場合, 回路 設計のデータベースに完全に反映させる必要がある。

PWB ユーザは PWBメーカにパターン設計を依 頼する場合が一般的であるが，ユーザ側でもパター ン設計を分担するケースが増加している。これは, 設計キャパシティの面では専門メーカに頼るもの の, 小変更などは自社内で行った方が効率的であり, また回路設計から部品実装ラインまでを一貫したデ ータベースで効率良く運用するためである。

したがって，この場合ユーザのメーカに対する要 求は, 自社保有と同一機種の CAD データベースで 設計結果を納入してもらい, 直ちに確認や改版がで きるようにすることである。また，この CAD 間イン タフェースは, PWBメーカにとってもユーザから ライブラリの支給を受けて入力工程の効率化を図っ たり, 設計協力会社との間でデータ送受を行う場合 などにメリットが大きい。

以上のようなデータベースレベルでのインタフェ ースは, 個々に変換ソフトを開発する試みがなされ ているが, 両者の設計思想の違いから変換されない データがあったり, 追加作業が発生したりで実用的 とはいえない。

したがって，現在これを完全に実現するには，メ ーカ側がューザ側と同一機種の CAD システムを保 有すればすべて解決する。しかし, 一般に PWB 設 計・製造メーカは数十社から数百社のユーザを顧客

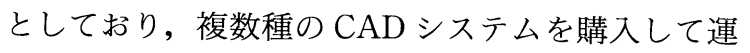
用するのは多大な投資と, ライブラリの不統一化な ど運用面の非効率化を招くことになる。

このため, CAD のデータフォーマット標準化は $\mathrm{PWB}$ 業界にとって最重要課題となっている。

\section{JPCA データフォーマット}

\section{1 検討の経緯}

91年11月に行われたDA91（デザインオートメー ション)のシンポジウムにおいて, 異機種 CAD シス テム間のデータフォーマットの統一化の要望が最も 多かったため, 日本プリント回路工業会 (JPCA) で
は各企業に参加を求め, 1992年 2 月よりデータフォ ーマット部会を発足させ, 各ワーキンググループに 分かれ，標準化フォーマットの集中審議を行ってき た。データフォーマット部会は東京大学の高木教授 を部会長とし，表 1 に示す 26 社の $\mathrm{CAD}$ ベンダおよ びューザが参加している。

1993年 5 月に VER. 1 の仕様が完成し, DA93で 報告とデモンストレーションを行い,さらに細部を 改良した上で 94 年 5 月に詳細な解説書を発行した。 現在, 各種 CAD と JPCA データフォーマット間イ ンタフェースを各社で開発中，あるいは一部運用に 入っている。また，1993年 5 月より技術推進委員会 と運用推進委員会を発足させ，普及のための体制を 整えている。

\section{2 フォーマットの概要}

JPCA データフォーマットは, PWB パターン設 計用 CAD の領域に限定したデータ交換用ファイル であり，図 2 に示すように各社の CAD システム間 でデー夕交換を行うことが目的である2)。

本フォーマットは 10 種類の標準カテゴリファイル から構成されており，それぞれのカテゴリファイル は個々に意味を持ち独立している。そのため，すべ てのカテゴリが備わっていなくとも目的に応じたデ ー夕交換が可能である。

また,本フォーマット以外のデー夕交換のために, データ交換する CAD システム間で取り決めた任意 のファイルを, 非標準カテゴリとして取り扱うこと が可能である。

表 1.JPCA データフォーマット部会メンバー

\begin{tabular}{|c|c|}
\hline 1. 旭光学工業 & 15. ユニテク \\
\hline 2.いづみやアイシー & 16. 横河ディジタルコンピュ \\
\hline 3. 内田洋行 & -夕 \\
\hline 4. オムロン & 17. ケイデンス・デザイン・ \\
\hline 5. キャディックス & システムズ \\
\hline 6. キョウデン & 18. 図研 \\
\hline 7 . . シューエィディ・ジャパン & 19. 日本レーカル・リダック \\
\hline 8. シャープ & 20. 富士通 \\
\hline 9. ズウド & 21. メンター・グラフィック \\
\hline 10. 創和設計 & ス・ジャパン \\
\hline 11. 東洋インキ製造 & 22. ソニー \\
\hline 12. 日本信号 & 23. 大日本スクリーン製造 \\
\hline 13. 日本電気 & 24. 東芝 \\
\hline $\begin{array}{l}\text { 14. 日立ソフトウェアエンジ } \\
\text { ニアリング }\end{array}$ & $\begin{array}{l}\text { 25. 日本シイエムケイ } \\
\text { 26. 日立精工 }\end{array}$ \\
\hline
\end{tabular}






図 2.JPCA フォーマットの構成

表 2.カラゴリの記述内容

\section{3 フォーマットの構成と特徵}

フォーマットを構成する 10 種類のカテゴリファイ ルの記述内容を，表 2 に示す3)。

\section{（1）ファイル管理情報}

他のすべてのカテゴリファイルに関する情報を記 述したもので，最初にアクセスされる必須ファイル である。フォーマット名称や使用可能なカテゴリフ アイル名の他に，長さの単位や部品名の桁数などの 制限值も記述するため，交換先の CAD の制限值内 かどうかを，他のカテゴリファイルを読むことなし に早期にチェックできる。

（2）管理情報

PWB の正式名称, 図番, 設計者名など PWB に関 する情報を記述している。これらにより, PWB に関 する情報を確認できるが，デー夕の互換をとるだけ なら本情報はなくてもよい。

（3）基本情報

PWB の仕様情報を記述したもので, 層数, ディフ オルトの線幅值・間げき值, 論理層の定義などを行 う。論理層は CAD で取り扱う仮想の設計層で, 例え ば図 3 のように優先度の高いシルクカット層を設け, 物理層へ合成展開することができる。

本ファイルは他のカテゴリファイルと重要な関連 を持つ基本ファイルであり，特にパターン情報の交 換を行う場合必須となる。

\begin{tabular}{|c|c|}
\hline カテゴリ名(ファイル拡張子) & 主な記述内容 \\
\hline $\begin{array}{l}\text { ファイル管理情報 } \\
\text { (FIL) }\end{array}$ & $\begin{array}{l}\text { ・インタフェース管理用情報記述 } \\
\text { (フォーマット名称, バージョン, } \\
\text { 出力カテゴリリスト, 作成日付) }\end{array}$ \\
\hline $\begin{array}{l}\text { 管理情報 } \\
\text { (MNG) }\end{array}$ & $\begin{array}{l}\text { •CAD データ管理用情報記述 } \\
\text { (プリント配線板名称, 図面名称, } \\
\text { 管理番号) }\end{array}$ \\
\hline $\begin{array}{l}\text { 基本情報 } \\
\text { (TEC) }\end{array}$ & $\begin{array}{l}\text { ・プリント配線板仕様情報記述 } \\
\text { (プリント配線板サイズ, 層数) } \\
\text { ・設計仕様情報記述（クリアラン } \\
\text { ス, 線幅） }\end{array}$ \\
\hline $\begin{array}{l}\text { 接続情報 } \\
(\mathrm{NET})\end{array}$ & $\begin{array}{l}\text { ・ネット情報記述 } \\
\text { •信号属性情報記述 (信号別配線制 } \\
\text { 限) }\end{array}$ \\
\hline $\begin{array}{c}\text { 部品構成情報 } \\
\text { (ELM) }\end{array}$ & $\begin{array}{l}\text { •部品の構成記述 (部品番号, 部品 } \\
\text { 種別, 実装形態, カタログ番号) }\end{array}$ \\
\hline $\begin{array}{c}\text { 形状ライブラリ情報 } \\
\text { (FLB) }\end{array}$ & $\begin{array}{l}\text { •形状ライブラリ (パッド登録) } \\
\text { •ホールライブラリ (ホール登録) } \\
\text { •スタックライブラリ (ピン, ビア } \\
\text { 登録) }\end{array}$ \\
\hline $\begin{array}{c}\text { 部品形状ライブラリ情報 } \\
(\mathrm{PRT}) \\
\end{array}$ & $\begin{array}{l}\text { •部品形状記述 (外形, ピン, シル } \\
\text { ク, 禁止領域文字列) }\end{array}$ \\
\hline $\begin{array}{l}\text { 部品配置情報 } \\
\quad(\mathrm{PLC})\end{array}$ & $\begin{array}{l}\text { •使用部品の内容 (部品番号, 形状 } \\
\text { 登録名) } \\
\text { •部品位置情報（座標, 回転角度, } \\
\text { 配置層） }\end{array}$ \\
\hline $\begin{array}{l}\text { 図形情報 } \\
\text { (FIG) }\end{array}$ & $\begin{array}{l}\text { •パターン, ビア, 文字等の図形情 } \\
\text { 報記述 } \\
\text { •図形の属性情報記述 (線種, 線幅, } \\
\text { 論理層, 塗り込み) }\end{array}$ \\
\hline $\begin{array}{c}\text { バックアノテーション情報 } \\
(\mathrm{BAI})\end{array}$ & $\begin{array}{l}\text { • 部品の追加/変更/削除情報記述 } \\
\text { ・ピンの追加/変更/削除情報記述 }\end{array}$ \\
\hline
\end{tabular}


論理層 : 301 優先度 : 10



図 3. 論理層の優先度と図形色区分

（4） 接続情報

$\mathrm{PWB}$ 上の部品ピンの接続状態と各信号の属性を 記述するものである。それぞれのネットは接続グル ープ名で区分され, 信号属性情報を定義することで, 同一電位であっても線幅や線長制限等により区分し た配線が可能である。

特にこの信号属性情報は, 等長配線・平行配線な どの電気特性関係や，パッドからのパターン引き出 し方向など，詳細な指定項目がある。

また，デジタルグラウンドとアナロググラウンド を 1 点アース接続する場合などに使用するため, 異 なる複数のネット間と特定部品ピンで結線する記述 もできる。

（5）部品構成情報

PWB で使用する部品について, それらの部品番 号と実装すべき部品形状データ等を組にして記述し たもので, 設計デー夕受け渡しを行う場合に必須フ アイルとなる。

部品番号は図形情報ファイルや部品配置情報ファ イルと関連づけるキーワードで, 全部品に付けられ るユニークな名称（IC10，R 2 など）であるが, こ
れに対応する部品形状ライブラリ名, 部品管理番号, 部品種別, 部品実装形態コード, などを本ファイル にて記述する。

なお，部品実装の形態はコード化して記述するも ので, 部品種別・実装面・部品回転の組み合わせで 表現される。

（6）形状ライブラリ情報

JPCA データフォーマットは，基本的にはひとつ の PWB の設計データを記述するためのものである が，単独でライブラリを作成し部品デー夕の交換を 各種 CAD 間で行ったり，マス夕的な外部ライブラ リとして運用することができる。扱えるライブラリ の種類は以下の 4 種である。

・部品形状ライブラリ 部品の物理的形状を記述

・形状ライブラリランドやレジストの大きさ などを登録

・ホールライブラリ ホール形状を登録

・スタックライブラリ 部品ピンを層ごとのラン ド形状の集合で表現する もの

形状ライブラリ情報は，この中で部品形状を除い た他のライブラリの総称である。図 4 にスタックの 概念を示す。

（7）部品形状ライブラリ情報

PWB の設計データを表現する際に必要な部品の 形状情報について記述するもので, 形状ライブラリ, ホールライブラリ，スタックライブラリの基本形状 情報を, 部品ピン番号や位置座標と組み合わせ, 部 品形状を構成する。また，ランドやホール情報以外

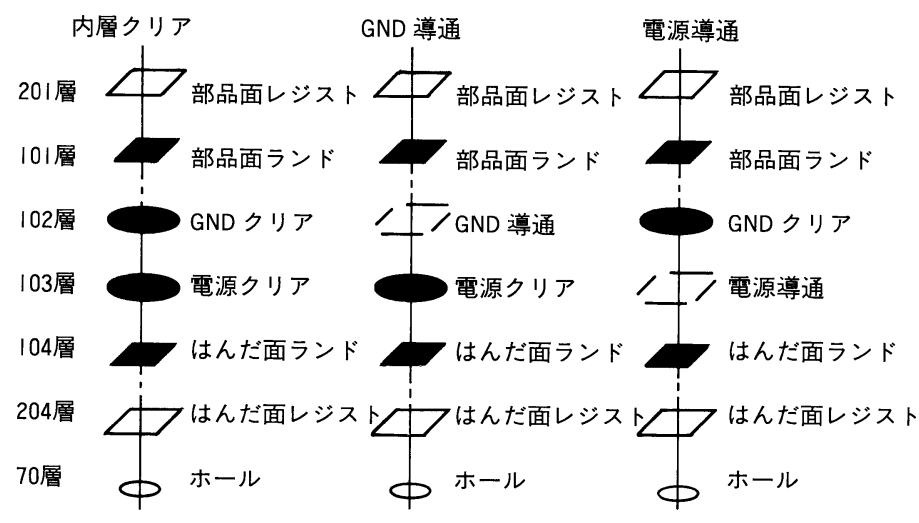

図 4、スタックの概念 
に部品に必要なビア/ライン禁止領域, 部品外形, シ ルクなどの構成も付加することができる。

\section{（8）部品配置情報}

PWB 上で使用されている部品の内容と配置状態 を記述したもので, 部品番号に対応する部品形状ラ イブラリ名, 位置座標, 回転角度, 配置層等から構 成される。位置座標は省略できるので, 未配置部品 を含んでも情報の受け渡しが可能であり，また位置 指定（移動禁止）ができたりして汎用性を考慮され ている。

\section{（9）図形情報}

パターンを構成する線分, 塗り込み図形, 文字等 の図形情報を記述するものである。特徴として,

・ポジ・ネガの概念を持ち, 組み合わせによりあ らゆる図形が表現できる

・形状ライブラリ内の登録図形の参照や置換が可
能

・論理層の指定により，一般的パターンの他に部 品配置禁止エリア, 寸法線, 外形など種々の情 報が表現できる

などがある。

(10）バックアノテーション情報

PWB 設計で実施した部品番号の付け替え, 部品 ピンの交換, 部品変更に関する内容を記述し, 本ファ イルで回路設計 CAD へ情報をフィードバックする。

(11) フォーマット記述例

ファイルの構造は, 各カテゴリ固有のファイル拡 張子を指定した HEAD 文で開始し, END 文で終了 するもので，その間にパラメータを持つ文を記述す る。例として, 基本情報ファイルおよび部品構成情 報ファイルの記述例を以下に示す。

\section{〔基本情報ファイル例〕}

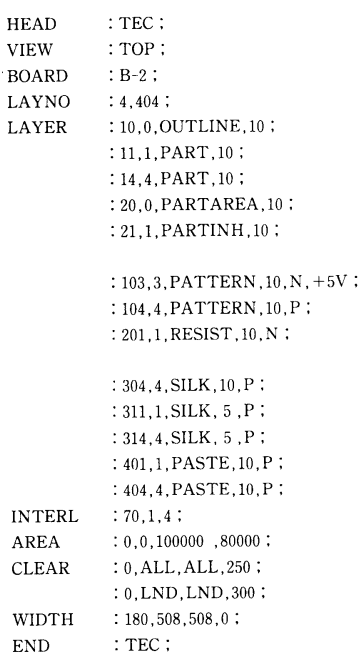

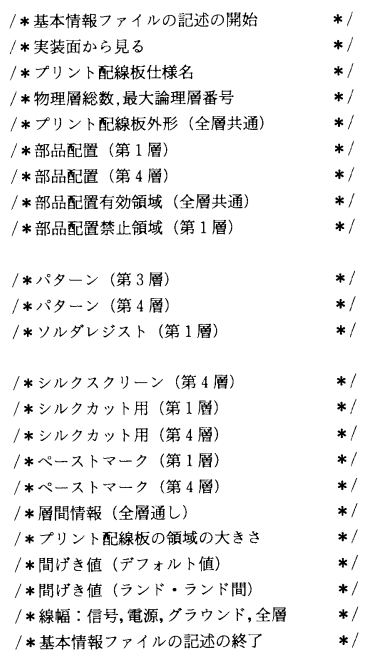

〔部品構成情報ファイル例〕
/*部品構成情報カテコリ開始*/

* 部品番号 : IC 10 各要素定䎹

* 部品形状登録名 : SOP20

/ * 部品管理番号 : B $-001-01$

* *実装形態コード：IST000

$<*$ 種別コード : IC

/*カタログ番号: JP74LS240

/*定数/定格：350mA

: R2,2125R,D-234-06,SDT000,REG.JPRC10,10K : 


\subsection{JPCA データフォーマットの運用}

運用方法は，すべての情報またはカテゴリ別に両 方向で情報交換を行う場合と, CAD の機能別に片方 向の入出力を行う場合がある。図 5 に運用例を示す。

なお, 日本プリント回路工業会では事務局内にデ ータフォーマット管理機関を設置し，運用促進活動 を行っている。

\section{EDIFフォーマット}

\section{1 検討の経緯}

EDIF は電気系設計情報の交換を容易に行うこと を目的に，1983年に開発が開始されたもので，85年 に最初の実用レベル版の EDIF100がリリースされ,

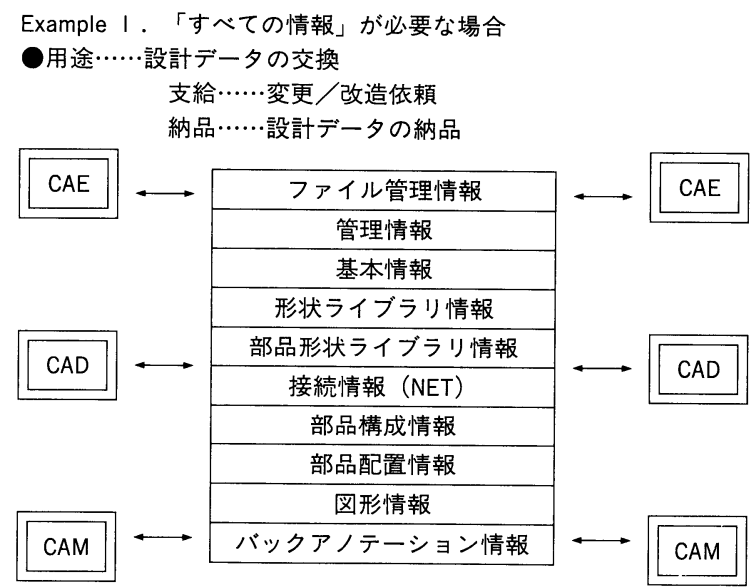

Example 2。「部品ライブラリ」のみ必要な場合

○用途……部品データの支給

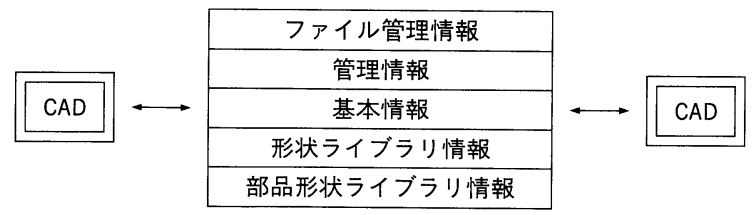

Example 3.「接続情報」と「バックアノテーション」の場合

○用途……ネッデータの支給

\begin{tabular}{|c|c|c|}
\hline \multirow{2}{*}{ CAE } & ファイル管理情報 & \\
\hline & 管理情報 & \multirow{2}{*}{$C A D$} \\
\hline \multirow{2}{*}{ CAD } & 基本情報 & \\
\hline & 接続情報（NET） & \\
\hline
\end{tabular}

○用途……バックアノテーションデータの支給

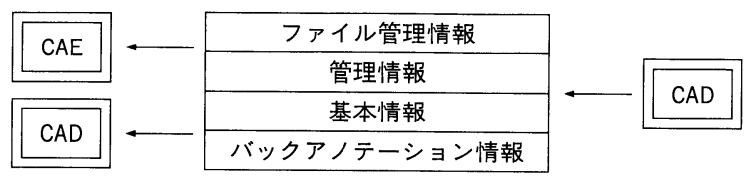

図 5 .JPCA フォーマット運用例
さらに，EDIF200が1987年に EIA 標準に制定され た。しかし，現状は種々の問題があり，改良版の EDIF300が1993年にリリースされたが，使用がネッ トリストとスケマティックに限られているため, 1989年中頃より PWB レイアウトの標準をV400と してリリースすべく, 検討が進められている。現在, 情報モデルや構文の作成がほぼ完了しており，1994 年末にドラフト版がリリースされる予定である。

検討組織はアメリカ, ヨーロッパの各 EDIF PCB TSC (Technical Sub-Committee) にて仕様が検討 される中で, 日本においても日本電子機械工業会 (EIAJ) の EDIF 小委員会の中の 1 つのワーキング グループとして91年 4 月より設置され，TSCより情 報を収集し，技術的検討と標準化推進のための活動 を進めている。表 3 に日本のワーキンググループの メンバーを示す ${ }^{4)}$ 。

\section{2 フォーマットの概要}

EDIF V400は PWB のレイアウト（部品配置・配 線）が対象範囲である。したがって，回路図エント リー, シミュレーション, CAM/CAT 出力は範囲外 となる。

EDIF はテキスト形式のフォーマットであるが, それを決めるために以下の4つのステージがある5)。

ステージ 1 : 概念モデルの作成

ステージ 2 : データディクショナリの作成

ステージ 3 : 情報モデルの作成

ステージ 4 ：フォーマットシンタックス（構文） 作成

概念モデルは，データの対象をモデリングしたも ので, EXPRESS-G という言語を用いて各デー夕項 目間の相関図を表現している。図 6 に例を示す。

データディクショナリは各データ要素の内容を説 明したものである。

表 3 . EDIF プリント配線板ワーキンググループ メンバー

\begin{tabular}{ll}
\hline ・シャープ & ・富士通 \\
・図研 & ・松下電器産業 \\
・ソニー & ・三菱電機 \\
・ 凸版印刷 & ・ヤマハ \\
・日本電気 & ・横河ディジタル・コンピュータ \\
・日立製作所 & ・メンター・グラフィックス・ジャパン \\
\hline
\end{tabular}


Stage I : Entity-Relations Diagrams (EXPRESS G)



図 6. 概念モデルの例

情報モデルはEXPRESS という言語を用いて概 念モデルを変換したものであり (図 7 ), さらに, そ の情報モデルを元にシンタックス(図 8 )を作成する。

\section{3 フォーマットの構成と特徵}

フォーマットは図 9 に示す 12 の大項目より構成さ れる5)。

Stage 3 : EXPRESS (Example)

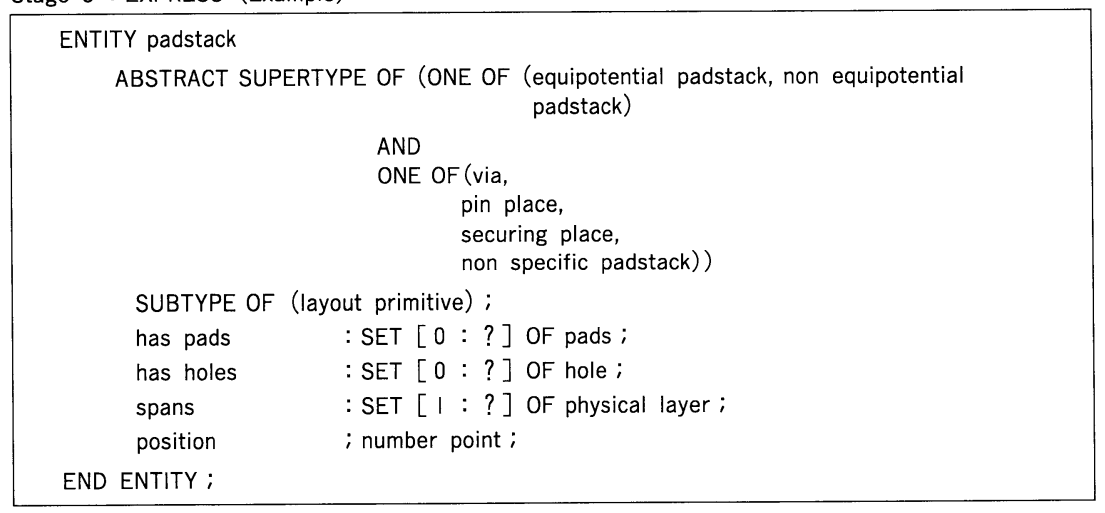

\section{図 7．情報モデルの例}

Stage 4 : New EDIF Syntax (Example)

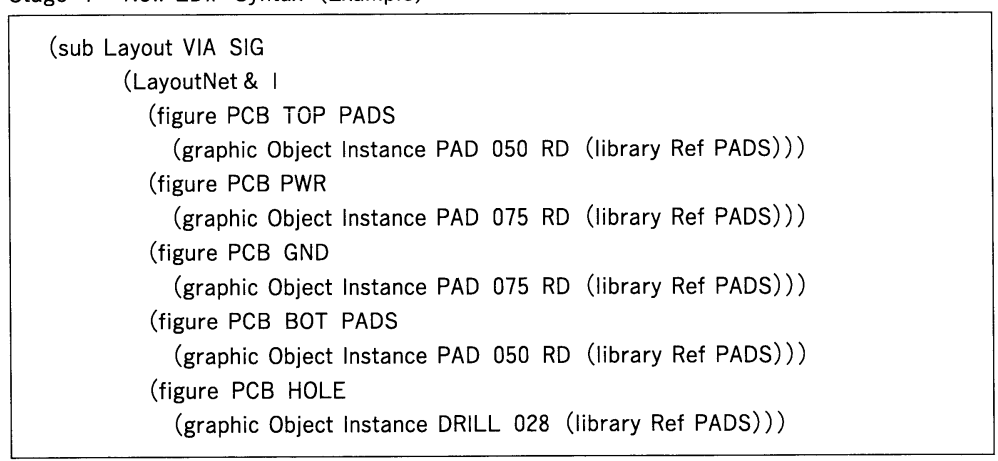

図 8.シンタックスの例 


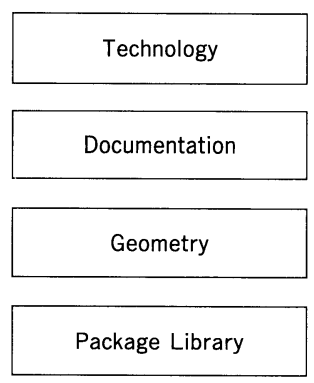

Package Library

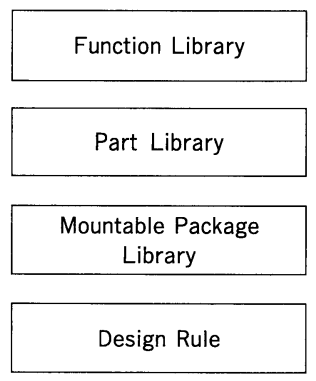

図 9.EDIF データ構成

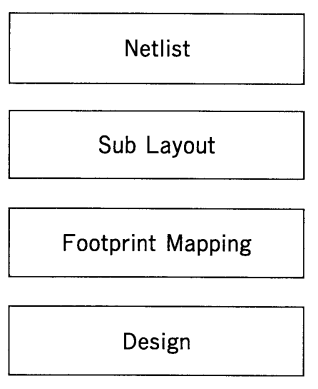

(1) Technology〔層定義〕

PWB の層数とその層構造や穴あけのルールを記 述したもので, 属性として各層の厚さの最大・最小 值や, 各層の材料参照名, ドリル径の最大・最小值 などを持っている。

(2) Documentation〔ドキュメント〕

PWBに関する 1 枚のドキュメントを表す。例と してアッセンブリ図, ドリル図など。属性は図面サ イズ，スケールなどを持つ。

(3) Geometry〔形状データ定義〕

多角形，矩形，円，線分などの基本図形と，これ らを操作した結果の図形集合から構成される。図形 操作はコピー, 加算, 減算, 回転, 拡大縮小などの 組み合わせが可能で, 複雑な形状を表現することが できる。

また，文字フォントや予約文字（ロゴなど）によ る文字列, 多角形の輪郭線幅, オフセット制御など, 多様な形状表現が可能である。

(4) Package Library〔部品形状ライブラリ〕

部品の物理的形状を定義するライブラリであり, 部品外形やピン位置, 部品の立体形状, ピン形状な どを記述する。属性は部品識別名, 部品種類など。

ピンは電気的な接続を行うものと, 補強ピンなど そうではないものに区分される。また，ICのように ピン位置が確定しているものと, リード線付抵抗の ように確定できないものも区分できる。

なお, 部品実装図のシンボルも含まれるが, シル ク図形は含まれない。

(5) Function Library〔素子ライブラリ〕

部品の論理的機能を定義するライブラリで, ゲー トの種類, 回路図におけるスケマティックシンボル, 端子の情報を記述する。端子の属性として, 入出力,
指定・高インピーダンス出力, 電源/GND など詳細 な指定が可能である。

(6) Part Library〔部品ライブラリ〕

部品を品種別に定義するライブラリで, 前述の部 品形状ライブラリ, 素子ライブラリを参照している。 部品の種別は電気的接続を行う部品と部品固定用ク リップのような非電気的部品に分類でき, さらにパ ッケージングされた部品と印刷抵抗のようなプリン 卜部品に分類される。また部品全体のスケマティッ クシンボルや端子情報も記述できる。

(7) Mountable Package Library

〔実装時に必要となる情報ライブラリ〕

本ライブラリは, 部品形状ライブラリと対応して, 部品実装時の部品形状を定義するものである。

図100例のように同一形状の部品であっても, 実 装方法により $\mathrm{PWB}$ 上のピン位置は変わる。また， 表面実装部品のフットプリントは部品そのものの形 状だけでは定まらず，実装方法により変化する。本 ライブラリはこれらの対応を行うもので, 実際の設 計はこの Mountable Package が参照される。

(8) Design Rule〔設計ルール〕

設計基準を表すもので，配線方向・線幅をエリア やネットを指定して細かく設定できる。また，実装 部品の配置条件(許容回転角度など) も設定できる。

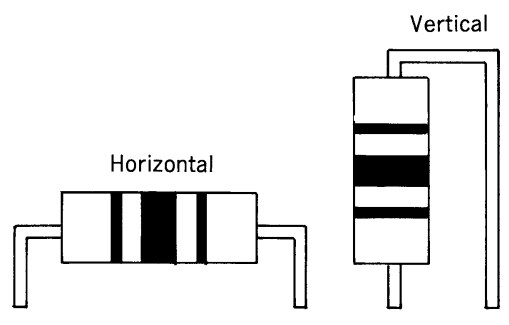

図10. 部品実装形状の違い 
(9) Net List〔ネットリスト〕

ネットリストを記述したもので，ゲート交換がで きるグループ指定が可能である。

(10) Sub Layout〔サブレイアウト〕

PWB のレイアウトパターンに含まれるあらゆる 要素を定義してグループ化し, 形状データと結びつ けるものである。スルーホールやラインの他にフッ トプリント, パッドスタック，テストクーポン，プ ローブポイントなどが定義できる。

(11) Footprint Mapping〔フットプリントマッピ ング」

部品実装形状とフットプリント定義を結びつける ための情報である。

(12) Design〔基板データ〕

PWB の個々の設計における部品リスト,ネット リスト, 端子, 実際の接続パターンなどを表現する。

ここでいうネットリストは前項(9)の機能レベルと は異なり, 部品の端子番号が明記されたものである。 現在本項目の大部分は Assembled Board と称さ れ独立して扔り，ジャンパー線の記述など，最終的 に基板に部品が実装された状態での表現となってい る。

\section{5. まとめ}

以上，PWBの CAD における $2 つ の$ 標準化フォ ーマットについて解説したが, ユーザからみると標 準フォーマットが複数存在するのは使いやすいとは いえない。現在，日本における EDIF のワーキング グループと JPCA データフォーマット部会は協調 して検討を進める方針を出しているが，両者の思想 の違いがあり，方向を合わすことはできても統合化 は困難と思われる。例えばEDIF はレイアウトに限 定しているとはいえ回路素子の記述や部品の立体構 造・実装方法など回路設計から実装までの広範囲を カバーしているのに対し, JPCA データフォーマッ トは PWBのレイアウト設計とベアボード製造に的 をしぼった実用的かつ比較的簡単な構造のものであ る。当面は後者が先行して普及していくと考えられ るが，これらの運用と使い分けをどのように考えて いくかが今後の課題である。

(1994.6.23-受理 1994.7.11-再受理)

\section{文献}

1) 星合文広：“SMT•高速化・高密度設計への CAD 技 術”，表面実装技術，1992年 5 月号

2 ）日本プリント回路工業会：“JPCA データフォーマ ットの概要”，1993年 5 月

3 ）日本プリント回路工業会：“JPCA データフォーマ ット解説書”, V1.0, 1994年 5 月

4 ）西山憲一：“EDIF プリント基板 WG 活動報告”, $\mathrm{EDA}$ テクノフェア，1993年 9 月

5 ) EDIF PCB TSC : “CONCEPTUAL MODEL OF A PCB”, August 31, 1993

\section{用語解説}

CAD/CAM : Computer Aided Design/ Computer Aided Manufacturing コンピュータ支援による設計・製造。

EIA : Electronic Industries Association 米国電子工業会

EDA : Electronics Design Automation

電子回路, LSI, PWB など電気系設計の自動化技 術の総称。

バックアノテーション：PWB のレイアウト設計の結 果, 部品名称やピン番号割り付けなどが元の回路設 計と異なる場合があるが，これらの情報を回路設計 のデータベースに戻すことをいう。

カテゴリファイル：データの用途ごとに区分したファ イルのこと。

ディフォルト：初期の設定值のこと。

スケマティック：論理回路図

CAM/CAT : Computer Aided Manufacturing /Computer Aided Testing コンピュータ支援による製造および検査。

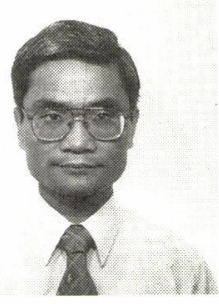

星合 文広 (ほしあい ふみひろ) 昭和 25 年生まれ。昭和 48 年, 静岡 大学工学部電気工学科卒業。現在, 日本電気株式会社電子部品事業本 部に扔いて，プリント配線板の $\mathrm{CAD}$ 技術開発に従事。 